\title{
A DÉL-KOREAI SOFT POWER: HALLYU
}

\author{
The South Korean soft power: hallyu
}

\author{
Fekete Anett ${ }^{1}$
}

\begin{abstract}
Absztrakt: A tanulmány célja, hogy megvizsgáljam a dél-koreai hullám (hallyu) hatását az ország puha hatalmával összefüggésben. A hallyu különböző részei, például a zene és a sorozatok nemzetközileg egyre nagyobb sikereket érnek el. Azonban ezzel nem csak az ország GDP-jéhez, hanem mint kiderült, nagy mértékben Dél-Korea puha hatalmának növekedéséhez is hozzájárult. Az elemzésem a Joseph S. Nye által meghatározott három alapvető puha hatalmi erőforrásokra épül, melyeket külön-külön elemeztem mind Kína, mind Dél-Korea esetében. Ezek az erőforrások a kultúra, a politikai értékek, ideológiák és a külpolitika. Az elemzésből egyrészt jól látszik, hogy Dél-Koreánál nagyon meghatározó a hallyu hatása, mind a kultúra terjesztése, mind a külpolitika területén. Másrészt pedig a jelen globális trendek miatt, mely az emberi jogokat védő és demokratikus berendezkedésú államokat részesíti előnyben, Kína hátrányban van. Ennek eredményeképpen jelenleg Dél-Koreának nagyobbak a puha hatalmi erôforrásai.
\end{abstract}

Kulcsszavak: Dél-Korea, hallyu, puha hatalom, Kína, dél-koreai hullám, külpolitika, hatalom, nemzetközi gazdálkodás

Abstract: The aim of this dissertation is to examine the effect of the South Korean Wave (hallyu) for the country's soft power. The different parts of the hallyu (e.g. music, series) have an increasing success on international scale as well. However, it turned out that this has not only contributed to the country's GDP but also to South Korea's soft power. My analysis has three basic pillars, which were defined by Joseph S. Nye, along which I compared South Korea and China. The pillars are the countries' cultures, ideologies and foreign policies. From the analysis we can see that the ballyu has a decisive influence on the culture and the foreign policy in South

1 A szerzőről: Fekete Anett a Budapesti Corvinus Egyetem Vezetés és szervezés mesterszakos hallgatója. Elérhetősége: feketeanett96@gmail.com 
Korea. On the other hand, Chine has a disadvantage, because the global trends prefer democracies. By analysing the three categories, it is turned out that currently South Korea's soft power is stronger than China's one.

Keywords: South Korea, soft power, China, South Korean Wave, foreign policy, power, international business

\section{BEVEZETÉS}

Tanulmányom célja, hogy megvizsgáljam a hallyu (vagy más néven koreai hullám) hatását a dél-koreai puha hatalomra és az ezzel együtt járó nemzetközi súly növekedésére. Az utóbbi időben egyre többször lehet hallani Dél-Koreáról, azon belül is a szórakoztatóipar úttörésérôl a nyugati kultúra felé, ezért egyre több kutatót érdekel, hogy mi is áll e jelenség mögött. Miután hozzám is elért ennek az új hullámnak a hatása, leginkább arra lettem kíváncsi, hogy ennek mekkora szerepe van az ország nemzetközi pozíciójára nézve.

Először azonban a ,soft power”, magyarul puha hatalom fogalomkörét érdemes megvizsgálni. Maga a jelenség bár nem újkeletű, de a köztudatba csak az 1990-es években Joseph S. Nye amerikai politológus munkássága révén került be. A puha hatalom lényege, hogy ellentétben a kemény hatalommal (hard power), nem erőszak útján érik el az országok azt, amit akarnak, hanem rá tudják venni a többi országot, hogy cselekedjenek úgy, ahogy ők szeretnék. A puha hatalom különböző forrásokon keresztül az adott ország nemzetközi reputációját befolyásolja. Annál erősebb egy állam puha hatalma, minél jobban elfogadott annak kultúrája és ideológiája, melyet a külpolitika segítségével lehet tovább terjeszteni.

Az elmélet megvizsgálása után megállapítható, hogy egyre fontosabb egy ország életében annak puha hatalmi pozíciója. Kutatásom során DélKorea és Kína hatalmi erőforrásait hasonlítottam össze, hiszen mindkét ország az elmúlt évtizedekben kezdett el jelentős mértékben fejlődni e tekintetben. A két ország történelmi és területi közelsége miatt azonban érdekes, hogy bizonyos esetekben mennyivel eltérő irányba indultak el a fejlődés területén (például politikai berendezkedést illetően). A makroökonómiai környezetük összehasonlítása után a puha hatalmi források tekintetében kezdtem el elemezni Kínát és Dél-Koreát. Ehhez, mivel maga a téma nehezen számszerűsíthető, mind korábbi tanulmányokat, mind Nye által meghatározott mérőszámokat egyaránt megvizsgáltam. 
Kutatásom során arra keresem a választ, hogy Dél-Korea a ballyunak köszönhetően több puha erőforrással rendelkezik-e. Ezen belül kérdés, hogy Dél-Koreának mind a három kategóriában (kultúra, ideológia és külpolitika) előnye van-e Kínához viszonyítva.

\section{ELMÉLETI ÁTTEKINTÉS}

\subsection{Puha hatalom (soft power)}

A „soft powver”, magyarra lefordítva puha hatalom fogalmát az 1990-es években alkotta meg egy amerikai politológus, Joseph S. Nye. Ez később széleskörben elterjedt fogalommá vált, elsősorban a nemzetközi politika területén, bár saját bevallása szerint főleg a hatalom és nemzetközi stratégiák elemzésének eszközének szánta. ${ }^{2}$ A következőkben a puha hatalom fogalmát, illetve jellemzőit mutatom be.

Először érdemes tisztázni, hogy mit értünk hatalom alatt: a hatalom „valamely akarat véghezviteléhez, terv, szándék megvalósításához szükséges erô, képesség, lehetőség, illetve a velük való élés" .3 Ugyanakkor Nye 2004es könyvében úgy fogalmazott, hogy a hatalom politikai és diplomáciai megközelítés szerint a népesség, a terület, a természeti erőforrások, a gazdasági méret, a katonai erők és a politikai stabilitás birtoklása. ${ }^{4}$ Eredetileg az, hogy melyik államnak mekkora ereje és hatalma volt, azt a háborúk során lehetett eldönteni, ez a nézet viszont napjainkra már egyre kevésbe igaz, hiszen a technológia fejlettség vagy a gazdasági növekedés sokkal nagyobb hangsúlyt kap az országok közötti „erőfitogtatásokban”. Ennek egyik oka Nye szerint az, hogy bár például a hadsereg még mindig egy erőteljes megvalósulása a hatalomnak, azonban ennek fenntartása egyre költségesebb az államok számára. Tehát a hatalom már nem csak a fizikai erőforrásoktól - mint például a hadsereg nagysága, nyersanyag mennyisége - függ, hanem egyéb, „megfoghatatlan” forrásai is vannak: kommunikáció, szervezeti és intézményi felépítés, valamint a függetlenség befolyásolásának képessége (függetlenség lehet biztonsági, kereskedelmi vagy pénzügyi). ${ }^{5}$

A gazdaság, a technológia folyamatos és nagyléptékű fejlődése, az Internet, az információáramlás és ezzel együtt a világpolitika fejlődése a

\footnotetext{
2 NYE, 2017.

3 BRÁCZ-ORSZÁGH, 2016.

${ }^{4}$ NYE, 2004.

5 NYE, 2004.
} 
nagy, tradicionális hatalommal rendelkező országok számára is jelentős változást hozott. Egyre több információ áll a rendelkezésünkre, amely kiveszi az irányítást bizonyos kormányok kezéből és egyre inkább az egymással való együttmúködés kerül előtérbe, a politikai színtereken is, hiszen sok problémát, mint például a környezetvédelemmel kapcsolatos ügyeket, csak így lehet megoldani. Azonban ezekben az együttmüködésekben is kérdés lehet az, hogy ki az, akinek a véleménye jobban érvényesül. $\mathrm{Ki}$ az, aki rá tudja venni másokat arra, hogy az ő véleménye szerint cselekedjenek. Ezt Nye puha hatalomnak („soft power”) nevezi. A puha hatolom röviden tehát az, amikor egy ország rá tud venni más országokat arra, hogy cselekedjenek úgy, ahogy az adott ország szeretné, míg a kemény hatalommal utasítja őket arra, hogy tegyék azt, amit ő akar. ${ }^{6}$ A puha hatalmat másnéven együttműködési hatalomnak nevezi, amely abban leledzik, hogy egy állam ötletei vagy politikai nézetei mennyire vonzóak mások számára és ezáltal mennyire tudja alakítani a többi állam nézeteit. ${ }^{7} \mathrm{~A}$ puha és a kemény hatalmak azonban nem zárják ki egymást, sốt egymást erősíthetik. Li és Hong szerint, a puha hatalom kialakulásához és megerősödéséhez szükséges egy bizonyos fokú kemény hatalom megléte, ugyanakkor a puha hatalom képes növelni a kemény hatalmat a kultúra, értékek és politika segítségével. Joseph S. Nye a puha hatalom forrásaiként a kultúrát, az ideológiát és a nemzetközi szervezeteket jelölte meg, míg a kemény hatalom elősorban gazdasági és katonai forrásokból ered. ${ }^{8}$

\subsubsection{Kultúra}

Az évtizedek során a kultúra, mint jelenség sok kutatót foglalkoztatott, és különféle fogalmakat és modelleket alkottak például Hall jéghegymodellje vagy Hofstede hagyma modellje. Malota a különféle kultúra felfogásokat ötvözve a következő definíciót adta a kultúrára: ,a kultúra egy adott társadalmi csoport közösen kialakított látható és láthatatlan rendszere, mely - hiedelmeken, normákon, értékeken, szimbólumokon, szabályokon, viselkedésformákon, standardokon, szokásokon keresztül - útmutatást, orientációt, életmódot és problémamegoldási sémákat nyújt tagjai számára". Ebből is látszik, hogy a kultúra nagyon sok elemből áll, sok minden

\footnotetext{
${ }^{6}$ NYE, 2004.

${ }^{7}$ NYE, 2004.

8 NYE, 2004.

${ }^{9}$ Malota, 2013.
} 
befolyásolhatja. Joseph Nye 2011-es könyvében a kultúrát univerzális, nemzeti és csoportokra jellemző kultúrává bontotta. Ha egy ország rendelkezik univerzális értékekkel és a többi nemzet által elfogadott politikával, az már egy jelentős puha hatalmi forrás lehet, bár általában a szűkebb rétegekre jellemző értékek és a populista kultúra az, ami jobban hozzájárul egy ország puha hatalmának kialakításához. ${ }^{10}$ Gondoljunk akár az amerikai filmek vagy zeneipar térnyerésére a hideg háború alatt, amikor például rock and rollt vagy jazzt játszani a kommunista országokban egyet jelentett az amerikai értékekkel való szimpátiával. ${ }^{11}$ A kultúra terjedésének egy másik nagyon fontos eleme a nyelv. Mivel az angol az egész világon elterjedt és a különböző nyelveket beszélők között sokszor ez jeleneti a hidat, ezért ennek segítségével sokkal könnyebb átadni az angolszász kultúra elemeit is. A kultúrából eredő puha hatalom mérése az exportált filmekből, TV músorokból, a zenei és könyv eladásokból és a külföldi tanulók arányából lehetséges. ${ }^{12}$

\subsubsection{Politikai értékek, ideológiák}

A politikai értékek és ideológiák csakis akkor jelentenek forrást a puha hatalomhoz, ha azokat mások elfogadják, illetve követésre méltónak $\operatorname{tartják}^{13}$. Egyik ilyen nagy hullám a kommunista ideológia terjedése volt, amely az egyik alapköve lett a Szovjetunió felemelkedésének. Manapság az USA és Európa által terjesztett demokratikus értékek és a szabadság eszméje a mérvadó. ${ }^{14}$ Egy jól meggondolt, és a nemzet érdekeivel is harmóniában lévő politikai érték, azon kívül, hogy az adott kormány belső hatalmát is erôsíti, segít a külső diplomáciai célok elérésében. Persze ehhez konzisztensnek és általánosan elfogadottnak kell lennie. ${ }^{15}$ Ahhoz, hogy minél több országba eljusson ez az ideológia, illetve, hogy ezáltal befolyásolni tudja a nemzetközi politikát, arra is szükség van, hogy minél több nemzetközi szervezet tagja legyen. ${ }^{16}$

\footnotetext{
${ }^{10}$ LIN-HONGTAO, 2017.

11 Hashimoto, 2018.

12 LiN-Hongtao, 2017.

${ }^{13}$ NYE, 2006.

14 NYE, 2004.

15 LiN-HongtAO, 2017.

16 Lin-HONGTAO, 2017.
} 


\subsubsection{Külpolitika}

Egy ország külpolitikája akkor járul hozzá annak puha hatalmának növekedéséhez, ha az törvényszerü és erkölcsi jogosultsággal bír. ${ }^{17}$ Joseph S. Nye leszögezi, hogy azok az államok nem lehetnek sikeresek, amelyeknek egyoldalú, arrogáns és csak a lokális környezetre fókuszáló külpolitikájuk van. Ha egy ország növelni akarja a külpolitikájának puha hatalomra gyakorolt hatását, akkor elsősorban a más országoknak adott segélyek és egyéb segítség mértékét, illetve az állam külső biztonságát kell növelni. ${ }^{18}$ Ezek a diplomáciai tevékenységek azonban fontos, hogy tükrözzék a politikai értékeket, illetve morálisan helyesek legyenek és ennek megfelelően rövid vagy hosszútávú kapcsolatok kiépítésében segítsenek, melynek következtében az adott ország népszerűsége, befolyásoló képessége, sőt gazdasági környezete is fejlődni fog. ${ }^{19}$ Annak megítélésére, hogy a nemzet által gyakorolt külpolitika ténylegesen pozitív vagy negatív hatással bír, a bevándorlók mennyisége egy jó mérőszám lehet. ${ }^{20}$

Joseph Nye emellett úgy gondolta, hogy az internet és a technológiai változások miatt az emberi jogok védelme és az NGO-k szerepe növekszik, és az információ is a hatalom egyik forrása lett. Ezek a hatalmi források (például az információ) viszont nem egységesen és egy helyen (esetleg országhatáron belül) találhatók, hanem sokkal szétszórtabban. De nem csak az információ, hanem az emberek is egyre szabadabban tudnak mozogni az országhatárok között, ami a kultúrák terjedésében is segít. Az egyes országok reputációja is sokkal fontosabbá válik és az állam egyik fő feladata a hitelesség megteremtése és fenntartása lesz. Ez a hitelesség, viszont a puha hatalmon is nyugszik és úgy lehet a legkönnyebben elérni, ha vagy [1] az ország domináns kultúrája közel van a globális trendekhez vagy [2] minél több kommunikációs csatornán keresztül terjeszti a nézeteit és befolyását az állam vagy ha [3] a hazai és nemzetközi teljesítménye következtében „kiérdemli” a bizalmat. Ezeket a technikákat alkalmazta és jelenleg is alkalmazza egyre több ország kisebb-nagyobb sikerrel. ${ }^{21}$

\footnotetext{
17 NYE, 2004.

18 LiN-HONGTAO, 2017.

${ }^{19}$ LiN-HONGTAO, 2017.

${ }^{20}$ LIN-HONGTAO, 2017.

${ }^{21}$ NYE, 2004.
} 


\subsection{Koreai hullám bemutatása}

\subsubsection{A hallyu eredete}

A 2000-es évek óta a ballyunak, mint jelenségnek az egész világon nagyon erőteljes hatása van, amely kiemeli a koreai kultúrát és a benne rejlő potenciált. A Dél-Korea által létrehozott popkultúra termékek magukban hordozzák a TV-drámákat, filmeket, K-popot, sőt napjainkra már a koreai élelmiszer kultúrára és az életmódra is kiterjed. ${ }^{22}$

A koreai háborút követően egy erôteljes növekedés vette kezdetét a dél-koreai gazdaságban. A történelme ugyanakkor sok helyen tartalmaz környező országok által megszállt időszakokat, mely során sok kulturális jellemzőt vettek át más népektől, például a konfucianizmus, buddhizmus vagy egyéb kínai szokások. Ez későbbiekben a popkultúrában is megjelenik. $^{23}$

A hallyu vagy más néven ,koreai hullám” kifejezést a kínai sajtó alakította ki a koreai popkultúra népszerúségére utalva Kínában. Maga a „hullám” a koreai televíziós drámák, úgynevezett k-drámák, Kínába való kivitelével kezdődött a kilencvenes évek végén. ${ }^{24}$ A folyamat az 1990-es évek második felében kezdődött, mikor a kínai köztévé elkezdte sugározni a "What is Love" (Mi a szerelem) című koreai dráma sorozatot, mely átütő sikert ért el. Az 1990-es évek közepétől azonban a zeneipar is egyre jobban elkezdett terjedni, elsősorban a környezô, ázsiai országokban.

A kínai és japán csatornák és rádiók elkezdték sugározni a koreai drámákat, melyek a koreai háború után segítettek az országok közötti feszültség csökkentésében, sőt egyesek szerint egy év alatt többet javult a helyzet, mintha azt a diplomaták egy évtized alatt próbálták volna megoldani. Kína után Japánba is betört a „Korea őrület”. A koreai filmek és drámák segítettek a japánoknak megváltoztatni a véleményüket a koreai emberekről, és sokkal udvariasabb, nagyvonalúbb és kifinomultabb kép kezdett bennük kirajzolódni róluk. Ezek a drámák számítottak a koreai kultúra első exportálásának. ${ }^{25}$

A 2000-es évektől elkezdett megváltozni a helyzet, egyre jobban a zeneipar került előtérbe. Ahogy az egész országra, erre az iparágra is nagy

\footnotetext{
22 KIM-BAE, 2017.

23 THE KOREAN WAVE, 2011.

24 THE KOREAN WAVE, 2011.

25 The Korean Wave, 2011.
} 
hatással volt a különféle országok (elsősorban Amerika és Japán) zenei stílusa, melyből - és a saját zenekultúrájukból - megszületett a ma K-popként ismert szórakoztatóipari múfaj. ${ }^{26} \mathrm{Az}$ itt híressé vált bandák tagjai igazi bálványokká váltak az emberek fejében, melyhez hozzájárultak az általuk előadott magas színvonalú koncertek is.

A közelmúltban a koreai popkultúra elkezdett terjedni a KözelKeleten, Afrikában, Európában és Amerikában a globális közönség felé. ${ }^{27}$ Sőt, a koreai kultúra egyre mélyebben és szélesebb körben veszi át a korábbi japán vagy amerikai popkultúra helyét, egyelőre elsősorban Ázsiában. ${ }^{28}$

A koreai popkultúra terjedésével maga a kultúra is elkezdett a külföldiek számára érdekes lenni. Egyre többen érkeztek azzal a céllal az országba, hogy a filmekben látott történelmi helyeket meglátogassák vagy az ételeket megkóstolják. Ezáltal maga a turizmus is fellendült az országban, amiben kimutathatóan nagy szerepe van a ballyunak mint jelenségnek. ${ }^{29}$

\subsubsection{A hallyu szakaszai}

Ahogy fentebb is olvasható, a hallyu kezdetben csak a távol-keleti országokban volt jelen, azonban mára már a világ minden táján ismerik. A különböző szakaszokat és csoportosításokat az 1. számú táblázat tartalmazza.

\begin{tabular}{|l|c|c|c|}
\hline & Hallyu 1.0 & Hallyu 2.0 & Hallyu 3.0 \\
\hline Időszak & $1995-2005$. & $2006-$ jelen & $\begin{array}{c}\text { Belátható idôn } \\
\text { belül }\end{array}$ \\
\hline $\begin{array}{l}\text { Érintett } \\
\text { országok }\end{array}$ & $\begin{array}{c}\text { Ázsia (Kína Japán, } \\
\text { Tajvan) }\end{array}$ & $\begin{array}{c}\text { Ázsia, Észak- } \\
\text { Amerika és } \\
\text { Európa }\end{array}$ & Az egész világ \\
\hline Cél & $\begin{array}{c}\text { Média kontent (K- } \\
\text { dráma és filmek) } \\
\text { (Termék-orientált) }\end{array}$ & $\begin{array}{c}\text { K-pop idolok } \\
\text { (K-sztár } \\
\text { orientáltság) }\end{array}$ & $\begin{array}{c}\text { Múfaj alapján } \\
\text { történő } \\
\text { diverzifikáció } \\
\text { (Sztár és Kreátor } \\
\text { márka orientáció) }\end{array}$ \\
\hline
\end{tabular}

\footnotetext{
26 The Korean WaVE, 2011.

27 THE KOREAN WAVE, 2011.

28 VISSER, 2002.

${ }^{29}$ LIM-GIOUVRIS, 2017.
} 


\begin{tabular}{|c|c|c|c|}
\hline $\begin{array}{l}\text { Kiemelkedő } \\
\text { anyagok }\end{array}$ & $\begin{array}{c}\text { „What is love? } \\
\text { (1992)”, „Winter } \\
\text { Sonata (2002)”, HOT } \\
\text { (banda), Boa (énekes) }\end{array}$ & $\begin{array}{c}\text { Girls' } \\
\text { Generation, } \\
\text { Kara, Shinee, Big } \\
\text { Bang, Black Pink, } \\
\text { EXO, BTS, } \\
\text { Gagnam Style }\end{array}$ & \\
\hline $\begin{array}{l}\text { Disztribúció } \\
\text { eszközei }\end{array}$ & $\begin{array}{c}\text { Külföldi koreai } \\
\text { társadalmi rétegek }\end{array}$ & $\begin{array}{l}\text { Online eszközök } \\
\text { (pl. YouTube) }\end{array}$ & $\begin{array}{c}\text { SNS (Social } \\
\text { Network Sites) }\end{array}$ \\
\hline Média & $\begin{array}{l}\text { Videó, CD, } \\
\text { Közvetítések }\end{array}$ & $\begin{array}{l}\text { Internet, helyi } \\
\text { fellépések }\end{array}$ & Cross-media \\
\hline Időtartam & $\begin{array}{l}\text { Hónapok vagy akár } \\
\text { évek }\end{array}$ & Éveken keresztül & $\begin{array}{l}\text { Évtizedeken } \\
\text { keresztül }\end{array}$ \\
\hline Iránya & $\begin{array}{l}\text { Turisztikai } \\
\text { központúság }\end{array}$ & $\begin{array}{l}\text { Tengeren túli } \\
\text { kiterjesztés és } \\
\text { fellépések }\end{array}$ & Minden ország \\
\hline
\end{tabular}

1. számú táblázat: A ballyu fejlődésének szakaszai. ${ }^{30}$

Az első szakasz a már korábban kifejtett 1.0 Hallyu időszaka volt, amikor is az 1990-es években elsősorban a koreai drámákkal betörtek a környező ázsiai piacokra. Azonban 2005-től egyre jobban a zeneipar kezdte vezérelni ezt a fellendülést, amit Hallyu 2.0-nak (K-pop zene) vagy másnéven neo-hallyu-nak is neveznek. A web 2.0-nak is nagy szerepe volt a kialakulásában, ugyanis a social networking oldalak és az okostelefon (mobil) segítségével a Hallyu 2.0 (K-pop őrület) az egész világon ismertté vált. Napjaink trendjeit vizsgálva viszont az látszik, hogy a "Hallyu 3.0" (Kkultúra) egyre népszerúbb lesz az Interneten, vagyis az írásjelektől, az ételeken át az öltözködésig egyre nagyobb ismertséget szerez magának a koreai kultúra. Ezt a koreai Kulturális és Sportügyi Minisztérium is intenzíven támogatja. A jövőre vetítve megvan az esély egy Hallyu 4.0-nak, amely a K-stílusról szól, vagyis a koreai identitás elterjesztéséről. Hiszen már a mai rajongók is egyre inkább a koreai sztárokhoz kötődő életstílust (étkezés, ruházat, szépségápolás stb.) akarják lemásolni, melyhez ezen sztárok (vagy ahogy Dél-Koreában hívják: idolok) személyiségéhez kapcsolódik. $^{31}$

A ballyu, vagy más néven koreai hullám tehát egyre nagyobb szerepet tölt be a koreai gazdaság megítélésben. Azok után, amin az ország átment a

\footnotetext{
30 BOKRAI, 015. 158.o.

31 BOK-RAE, 2015.
} 
történelme során (megszállások, gyarmatosítás, háborúk) nagyon is erôs benyomást kelt, hogy mára már a világ 29 . legversenyképesebb országa. ${ }^{32} \mathrm{~A}$ fejlődés azonban még valószínűleg nem állt le, egyre több és több ország szerez tudomást Dél-Koreáról, melynek elég erôs hatásai lesznek a turizmusra, az exportra, a nemzetközi kapcsolatokra és a gazdaság további fejlődésére egyaránt.

\section{MÓDSZERTAN LEÍRÁSA}

Tanulmányom során Joseph Nye által meghatározott puha hatalmi forrásokat fogom vizsgálni Kínára és Dél-Koreára nézve. Kutatásom célja, hogy meghatározzam, mekkora szerepe van a hallyunak a dél-koreai puha hatalom és az ezzel együtt járó nemzetközi súly növekedésében.

A puha hatalom elmélete azt állítja, hogy vannak különféle források, amiket, ha fejlesztenek az országok, figyelmet és energiát fordítanak rá, akkor azok segítségével növelhetik a puha hatalmukat, ezáltal a nemzetközi kapcsolatokban és gazdaságban elfoglalt helyüket is. Illetve, mivel a puha és a kemény hatalom nem független egymástól, ezért megéri abba invesztálni, amelyiket olcsóbb megvalósítani. Mivel a kemény hatalmi források, például a katonai erők fenntartása egyre költségesebb, és az ország hírnevének sem tesz jót, ezért egyre több ország fordul a kultúrából, ideológiából és külpolitikából származó hatalom felé. Az viszont, hogy ezt milyen hatékonysággal csinálják, az eltérő.

A kutatás során a puha hatalmi erőforrásokat, vagyis a kultúrát (és annak mások általi szimpátiáját), a politikai értékeket és a külpolitikát (és hogy az mennyire legitim és erkölcsileg elfogadható) egyesével megvizsgálom, mind Kínára, mind Dél-Koreára nézve. Ehhez egyrészt korábbi tanulmányokat használok fel, másrészt a koreai és a kínai statisztikai hivatal adatait, illetve egyéb állami szervezetek forrásait. Az adatforrásoknál egyes elemeket változatlanul átemeltem, míg másokat több adatforrásból, például különböző évekből származó évkönyv alapján szerkesztettem össze és vetítettem le egy főre vagy arányosítottam a népességhez viszonyítva. Mind a három puha hatalom forrásnál Lin és Hongtao 2017-es tanulmányában leírt, Joseph S. Nye munkásságában is megjelenő kvantitatív kritériumokat is megvizsgálom. A célom, hogy szemléltessem a Kína és Dél-Korea közötti hasonlóságokat és különbségeket, illetve a hallyu hatását is próbálom ezen

32 KOREA IN THE WORLD, 2018. 
keresztül mérni. Kutatásomnak nem célja egy konkrét stratégia megalkotása a puha hatalomra nézve.

A módszer korlátja abban rejlik, hogy vannak bizonyos tényezők, amelyek nagyon szubjektívek, például a kultúra szimpatikussága. Ezeket a nehezen számszerűsíthető tényezőket előző kutatások alapján próbálom kiküszöbölni. Másrészt az objektív, vagyis számszerűen leírható részeknél az országok nagysága közötti különbség is egy probléma, ezért több mutatót is az adott évi aktuális népességszámra vetítve vizsgáltam.

\section{A PUHA HATALMI FORRÁSOK ELEMZÉSE}

\subsection{Kultúra}

Ahogy az elmélet bemutatásánál is írtam, a kultúra a puha hatalom egyik alapköve. Azok a nemzetek, akik szélesebb körben elfogadott kultúrával rendelkeznek, könnyebben válnak vezető szereplővé a világgazdasági színtéren is. Mérésére az exportált filmek és TV műsorok számát, a zenei és könyv eladásokat és a külföldi tanulók arányát használom fel.

\subsubsection{Kína kultúrája}

A kínai kultúra közel 4 ezer évre visszavezethető történelmi háttérrel rendelkezik, mely során az ország többféle kulturális változáson is keresztülment, de mégis mindegyik egy közös tőről fakad. ${ }^{33}$ A Han dinasztia óta van egy ideológia, amely nagymértékben meghatározza a kínai gondolkodást, amely később a legtöbb ázsiai országban is elterjedté vált és egyfajta közös ázsiai tudat részét képezi: a konfucianizmus ${ }^{34}$. Azonban a kultúra elterjedését nagymértékben nehezíti a regionális heterogenitás, illetve az, hogy a nyugati kultúrkörökbe már nagyon mélyen bele van ivódva a demokrácia, szólásszabadság és az emberi jogok nagymértékủ tiszteletben tartása. ${ }^{35}$

\footnotetext{
33 ZHANG, 2017.

34 ZHAO, 2015.

35 JORDÁN, 2010.
} 


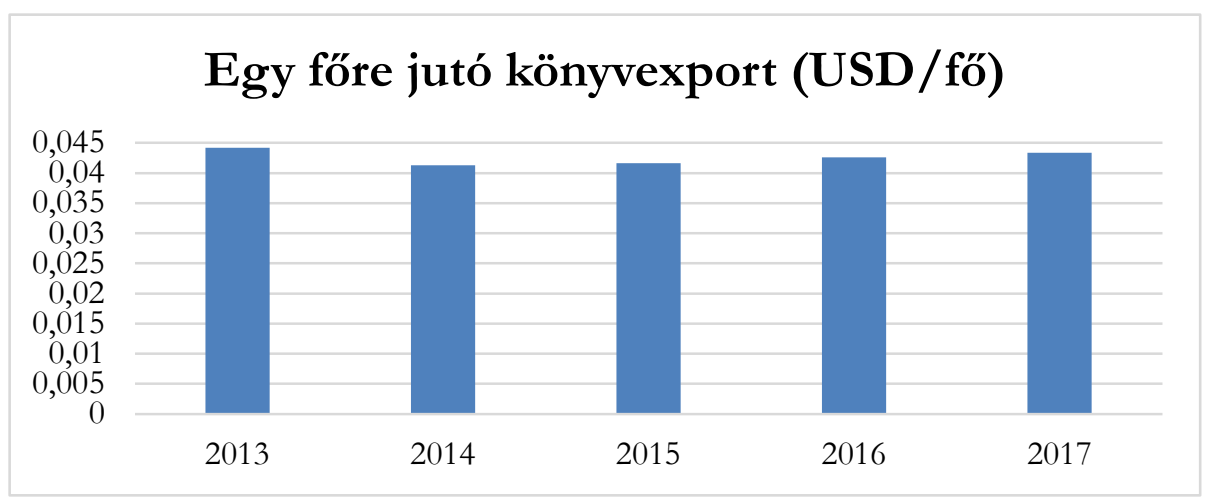

1. számú ábra: Egy főre jutó könyvexport USA dollárban. ${ }^{36}$

A könyvnyomtatás és eladás, mint a kultúra terjedésének és elfogadottságának egyik mutatója, Kínánál eléggé korlátozott. Ennek fő oka a nyelvi korlátok, vagyis az, hogy Kínán kívül viszonylag alacsony az olvasottsága a kínaiul îrt könyveknek. ${ }^{37}$ Ennek egyik mutatója, hogy míg külföldről 4000 könyvet importáltak, addig csak 24 darabot exportáltak. ${ }^{38}$ Ezen a kínai állam az úgynevezett Kínai Konfucius Központok alapításával próbált meg javítani, amelyek a kínai nyelv tanulására ösztönzik az embereket. ${ }^{39}$ A kínai kormánynak ezzel az a célja, hogy a mandarin nyelv elsősorban Ázsiában - egy lingua franca-vá váljon és az üzleti életben is ez legyen az elsődleges tárgyalási nyelv. ${ }^{40} \mathrm{Az} 1$. ábrán viszont azt láthatjuk, hogy az elmúlt években nem történt nagy változás az egy före jutó könyvexport terén. A 2014-es visszaesést egy minimális, de növekvő trend követi, ami viszont jó jel a nyelv elterjesztésének szempontjából is.

Kína az elmúlt időben próbálja a filmek, könyvek és videók importexportját is javítani, vagyis minél több kínai média exportot gyártani, melynek segítségével tudja a saját kultúráját népszerűsíteni. Ennek a lépésnek az egyik oka a koreai hullám okozta nagy média beáramlás az országba. A kínai nyelvtanulást ösztönző Konfucius Központok terjedésével azonban kezd kialakulni egy Dél-Korea - Kína kapcsolat, melyben a koreai hullám és az úgynevezett kínai szél találkozik. Ennek keretében közel 70

\footnotetext{
36 : Saját szerkesztés a Kínai Statisztikai Hivatal évkönyvei alapján (National Bureau Statistics of China, 2019)

37 ZHANG, 2017.

38 MiNGIJANG, 2008.

39 ZHAO, 2015.

40 JORDÁN, 2010.
} 
ezer diák tanulhat Kínában és 50 ezer Dél-Koreában. ${ }^{41}$ Másrészt Kína a nemzetközi színtéren is eddig hátul szerepelt a médiatartalom gyártásában a nyugati trendekhez képest. ${ }^{42}$ A kulturális kereskedelmi deficit napvilágra kerülése után azonban a filmiparban is elkezdődtek a fejlesztések és Kína egyre több és több filmet gyárt és exportál. ${ }^{43} \mathrm{Ez}$ a siker viszont a televíziós iparra nem igaz, ugyanis a koreai tv drámák 2003 után egyre jobban ellepték a kínai piacot. ${ }^{44}$

Kínában a külföldi diákok közötti megoszlását a 2. számú ábraegyüttes mutatják. Ezekből jól látszik, hogy a külföldről érkező diákok aránya még az 1\%-ot sem éri el az összes kínai diákhoz képest (pontosan csak $0,02 \%$, bár abszolút értékben nézve ez több, mint 445 ezer főt jelent. ${ }^{45}$ A külföldi diákok száma azonban folyamatosan növekszik, 2017-ről 2018-ra például $7 \%-\mathrm{kal}^{46}$. A külföldi diákok között jelentős a Dél-Koreából érkezettek aránya, melynek oka a korábbi diplomáciai megegyezések.
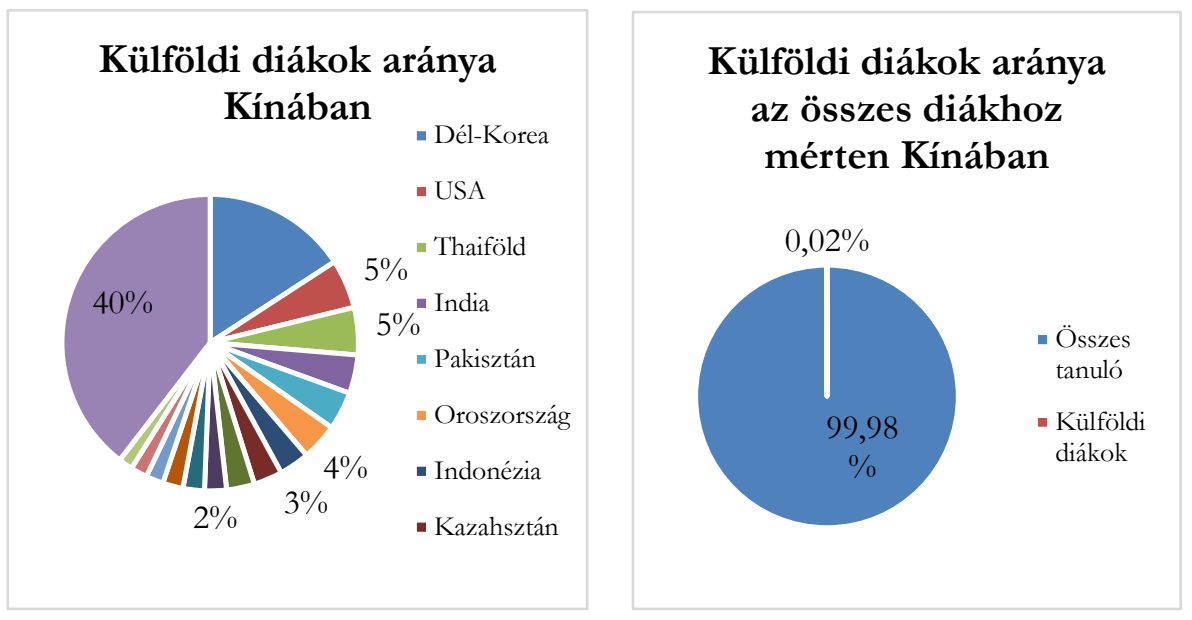

2. számú ábraegyüttes: A külföldi diákok megoszlása Kínában. ${ }^{47}$

\footnotetext{
${ }^{41}$ ZHAO, 2015.

42 Mingjiang, 2008.

${ }^{43}$ KEAN, 2010.

44 KEAN, 2010.

45 MinistRy OF EDUCATION (CHINA) (2016)

46 Ministry. OF EDUCATION, 2019.

${ }^{47}$ Ministry of Education (China) (2016) és saját szerkesztés a Ministry of Edcation (China) (2019) és a Kínai Statisztikai Hivatal évkönyveiből (2019).
} 
A filmgyártást tekintve, egy növekvő tendenciát figyelhetünk meg, amely Kína elkötelezettségét is mutatja a nagyobb mennyiségü filmek gyártására és exportálására.

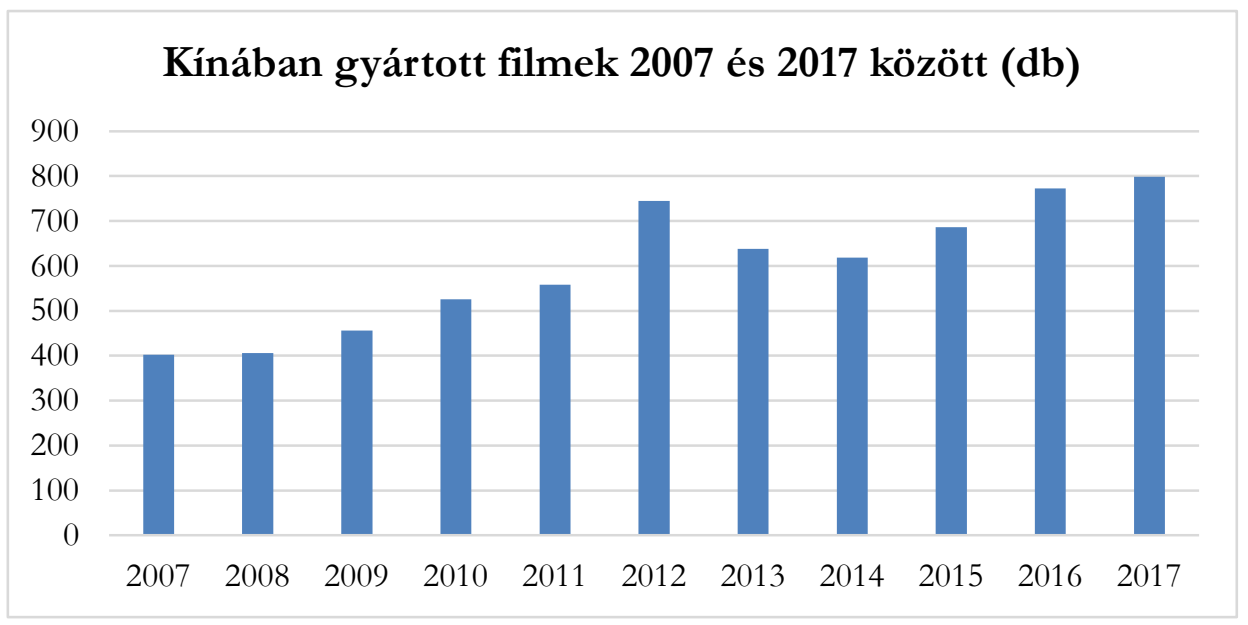

2. számú ábra: A Kínában gyártott filmek darabszáma 2007. és 2017. között. ${ }^{48}$

Azonban, mivel a kutatásom egyik célja az összehasonlíthatóság, ezért az egy főre jutó filmek arányát is megvizsgáltam, mely szerint 2017-ben kevesebb, mint 0,006 darab film jutott egy före.

A kínai zeneipari exporton is hasonló tendenciát figyelhetünk meg, mint a könyveknél. Egy kisebb visszaesést követően az elmúlt években növekedett a külföldre értékesített zenék egy főre jutó nagysága (3. számú ábra). Az export fő célországai Ázsiában találhatóak, de Latin-Amerikába és Afrikába is egyre több TV műsort exportálnak.

48 Xinhua News Agency (2018) 


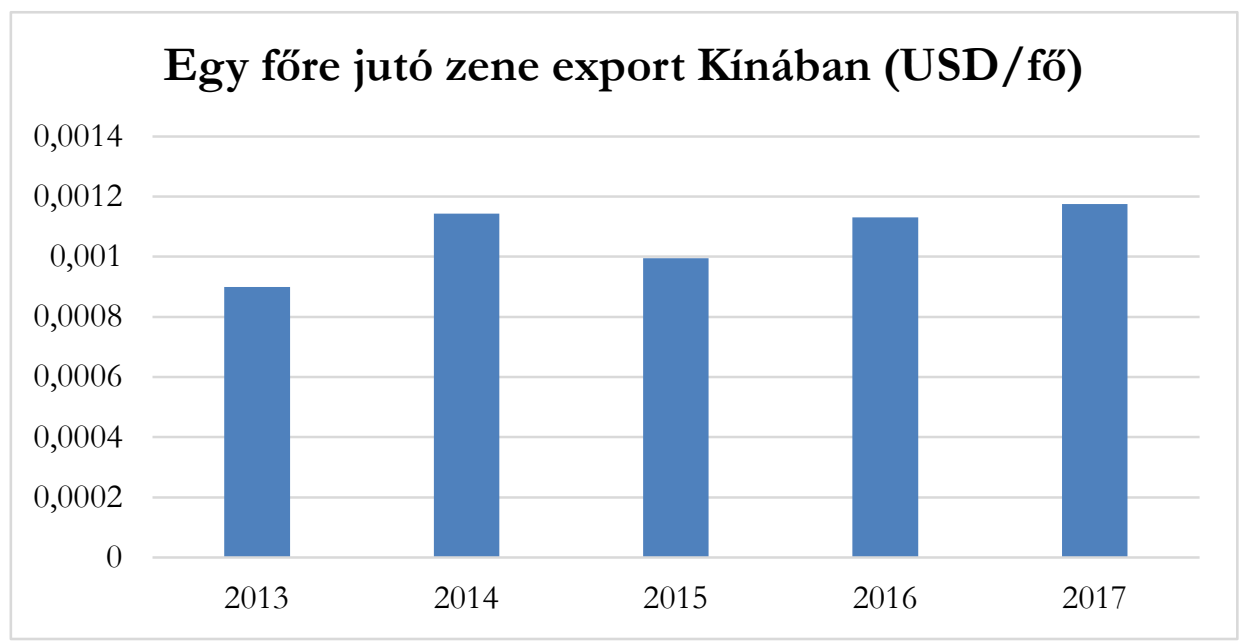

3. számú ábra: Egy főre jutó zenexport Kínában USA dollár/fő. ${ }^{49}$

Ahogy a TV músorok, film és könyvgyártásnál is látszik, az elmúlt években növekvő tendencia figyelhető meg Kína média exportjában. A külföldről érkező diákok aránya viszont nem túl jó, ennek oka lehet a nyelvi korlát és a nagy kulturális különbség. Összességében tehát látszik, hogy Kína egyre jobban figyel a média reputációjára, azonban még hosszú fejlődés áll előtte.

\subsubsection{Korea kultúrája}

Korea történelme során több hódoltságot átélt (például mongol vagy japán), illetve a XX. századtól az amerikai befolyás is erőteljes volt. DélKoreában, Kínához hasonlóan, a konfucianizmus volt a legmeghatározóbb nézet, amely a kultúrát is jelentősen befolyásolta. A koreai írásjelek viszont nagyon logikusak és könnyen tanulhatók, mivel a XV. században azzal a céllal hozták létre, hogy mindenki, akár vidéki írástudatlan emberek is könnyen elsajátíthassák. A könnyebb tanulhatóság viszont hozzájárul a kultúra terjedéséhez is. ${ }^{50}$

\footnotetext{
${ }^{49}$ Saját szerkesztés a Kínai Statisztikai Hivatal 2014-2018-as évkönyvei alapján ${ }^{50}$ CSOMA, 2013.
} 
A koreai kultúra népszerüsítésének legjelentősebb eszközei a hallyu, vagyis a koreai hullám. Ennek legfőbb elemei a televíziós drámák, a zene és a filmek, de nagy szerepe van a táncnak, divatnak, videójátékoknak és a koreai tradicionális ételeknek is. A hallyu mindezekkel abban segít, hogy a dél-koreai kultúrát minél szélesebb körben megismerjék az emberek és egy pozitív kép alakuljon ki bennük az országról. Ennek a képnek a kialakításában a hírességeknek nagy szerepe van, egyesek egyfajta szimbólummá válnak. ${ }^{51}$

Ha az adatokat nézzük, akkor azt figyelhetjük meg, hogy DélKoreában a 2010-es évektől kezdve egyre nagyobb mértékű a zeneipari export és ezáltal az egy före jutó export (dollárban) nézve is egyre növekszik (4. és 5. számú ábra).

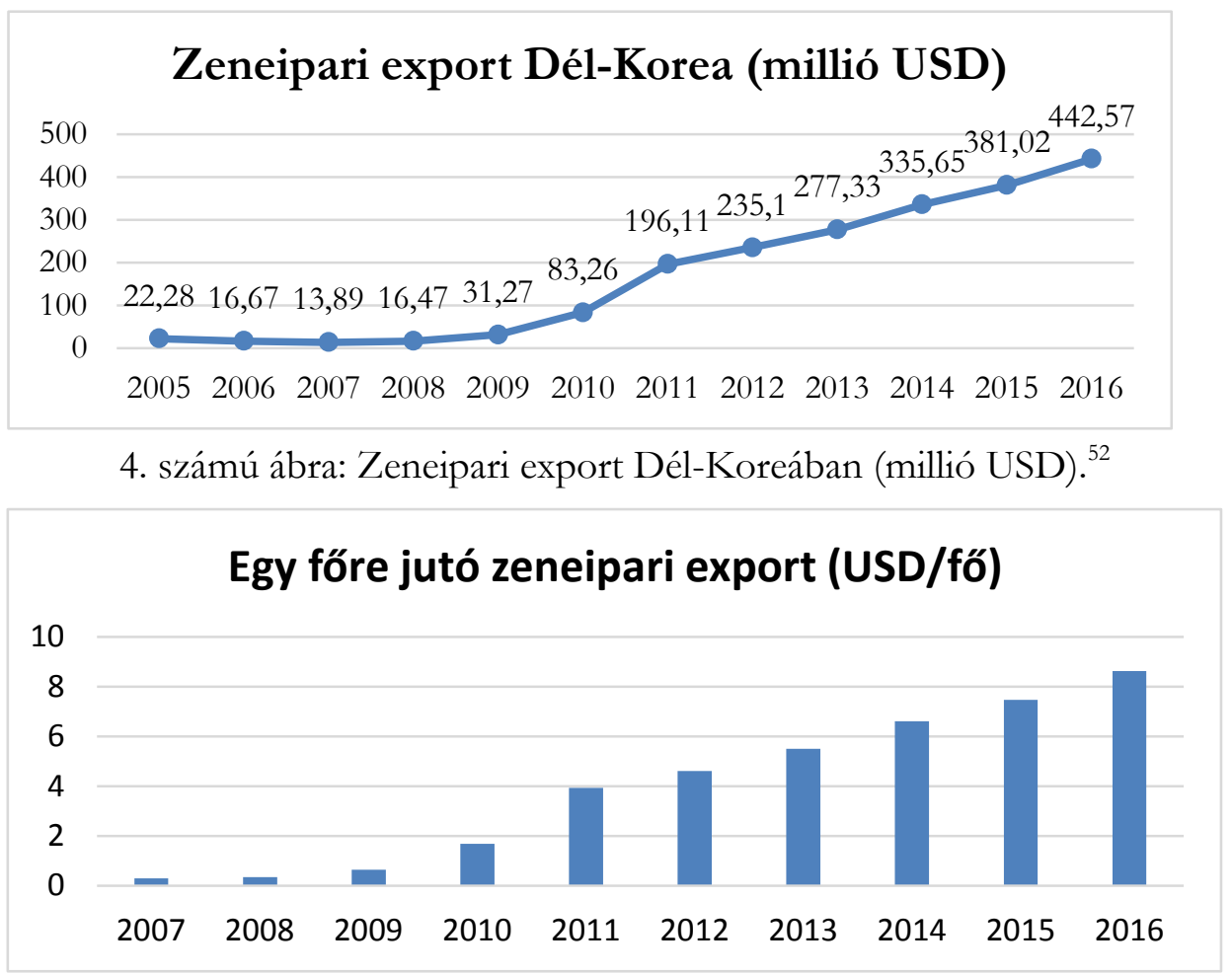

5. számú ábra: Egy főre jutó zeneiapri export Dél-Koreában (USD/fő). ${ }^{53}$

51 LEE, 2009.

52 Statistics Korea (2018)

${ }^{53}$ Saját szerkesztés a Koreai Statisztikai Hivatal adatbázisából (Statistics Korea, 2018) 
A filmiparnál érdekes megfigyelni a dél-koreai és a külföldi filmek arányát. Míg például Magyarországon a mozikban vetített filmek maximum 10-15\%-át adják az itthon gyártott filmek ${ }^{54}$, addig Koreában ez az arány $50 \%$ feletti (6. számú ábra). Emellett az elmúlt években egyre több filmet gyártanak Dél-Koreában, amelyet a 7 . számú ábra mutat. Igaz, elsőre úgy tűnik, hogy viszonylag kevés, olyan 300 db filmet gyártanak le egy évben, azonban, ha a piac méretét is figyelembe vesszük, akkor már más a helyzet. Hiszen például Amerika, amelynek piaca sokkal nagyobb, mint Koreáé, csak kétszer több filmet gyárt le egy évben.

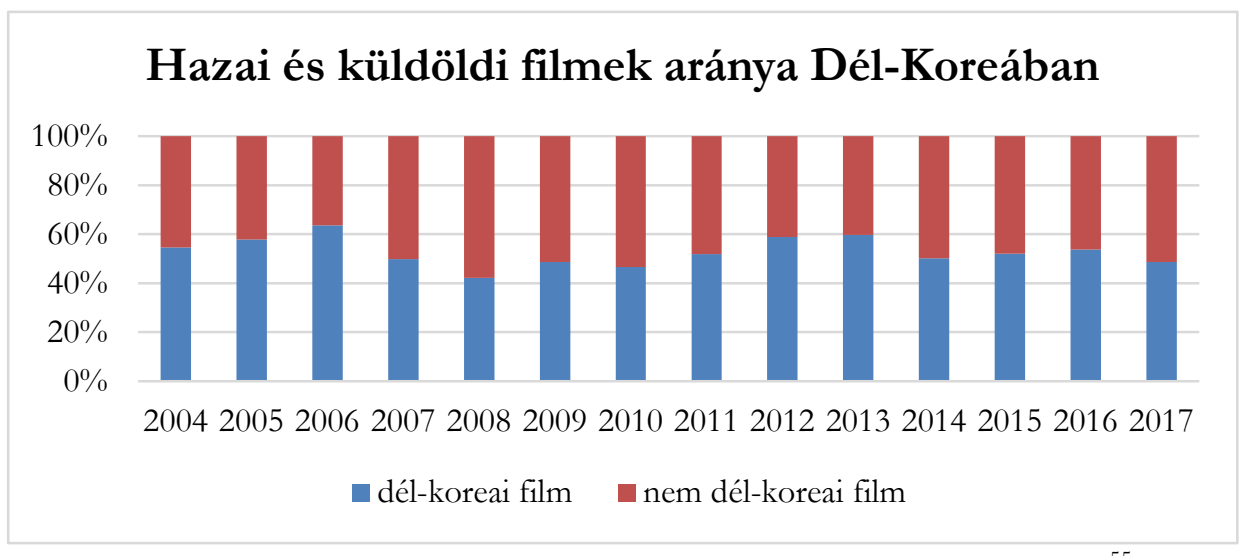

6. számú ábra: Hazai és külföldi filmek aránya Dél-Koreában. ${ }^{55}$

\footnotetext{
${ }^{54} \mathrm{KSH}, 2006$.

${ }^{55} \mathrm{KOFIC}(2019)$
} 


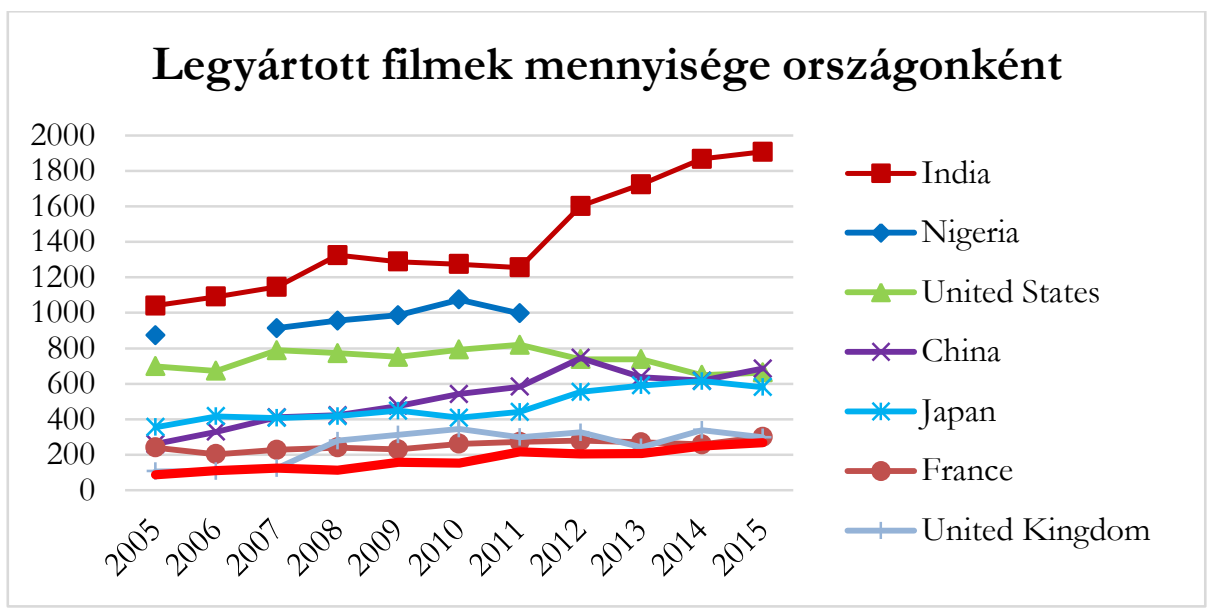

7. számú ábra: Legyártott filmek mennyisége országonként. ${ }^{56}$

Forrás: Miroudot (2019) 56. oldal

A 8. számú ábrán a 2015 és 2017 között legyártott filmek mennyiségét, illetve annak egy főre jutó nagyságát láthatjuk. Míg 2015-ben 269 filmet gyártottak, addig 2017-re ez a szám 436-ra növekedett, vagyis több, mint 1,5-szeresére 2 év alatt. A növekvő tendencia az egy főre jutó arányokon is látszik, amely jóval magasabb, mint a kínai $(0,08$, illetve. 0,006 film/fö).

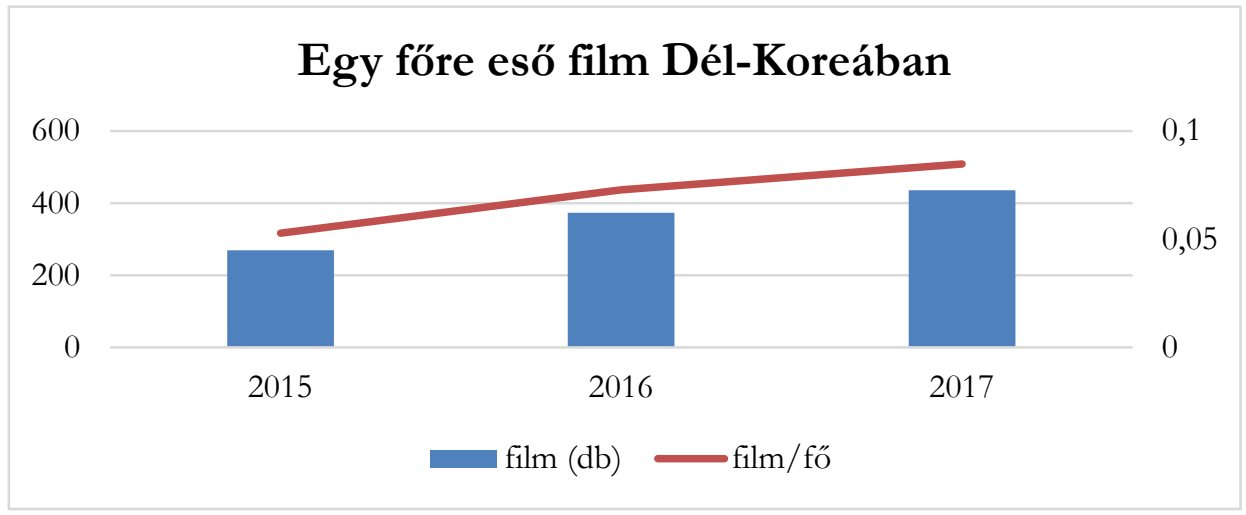

8. számú ábra: Egy főre eső legyártott film mennyisége Dél-Koreában. ${ }^{57}$

56 Miroudot (2019) 56.o.

57 Saját szerkesztés a Koreai Statistikai Hivatal (KOSIS, 2019a) és a Korean Film Council (2019) adatai alapján. 
A könyvek, magazinok és újságok exportjánál érdekesség, hogy az előzőekben felvázolt trendekkel ellentétben, itt inkább egy csökkenő tendenciát mutat. Azonban ez csak a nyomtatott könyveket és újságokat tartalmazza. Az e-book és online magazinok értékesítése viszont növekszik, amely magyarázhatja a tradicionális, nyomtatott változatok értékesítésének csökkenését.
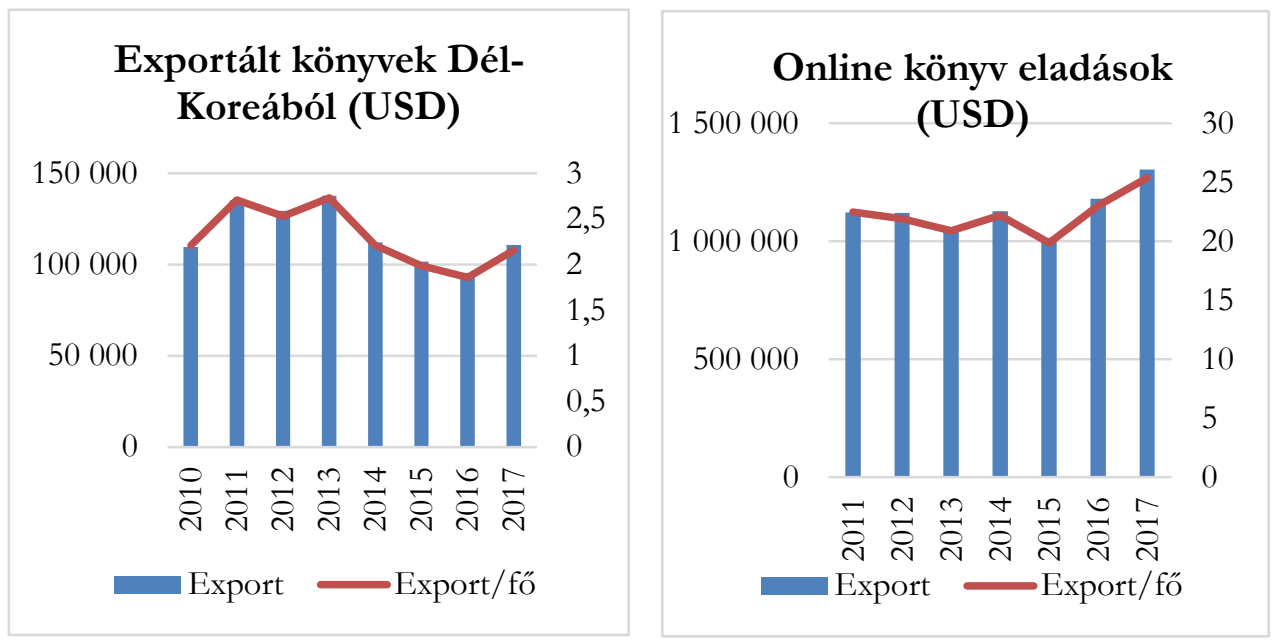

9. számú ábraegyüttes: A Dél-Koreából exportált könyvek értéke (USD), valamint az online könyveladások értéke Dél-Koreában (USD). ${ }^{58}$

A külföldi diákok aránya jobb, mint Kínánál (1\% körüli), de a diákok arányából jól látszik, hogy a legtöbben Északkelet-Ázsiából, azon belül is Kínából érkeznek (10. ábraegyüttes). Érdekes, hogy csak viszonylag kis százaléka a külföldi diákoknak származik Amerikából. A nemzetközi tanulók aránya azonban az elmúlt években növekedett, 2008 óta 1,5-szeresére nőtt a Koreában tanuló külföldi diákok száma ${ }^{59}$.

\footnotetext{
${ }^{58}$ Trade Map (2019) és Statistics Korea (2019)

${ }^{59}$ KOSIS, 2019C.
} 


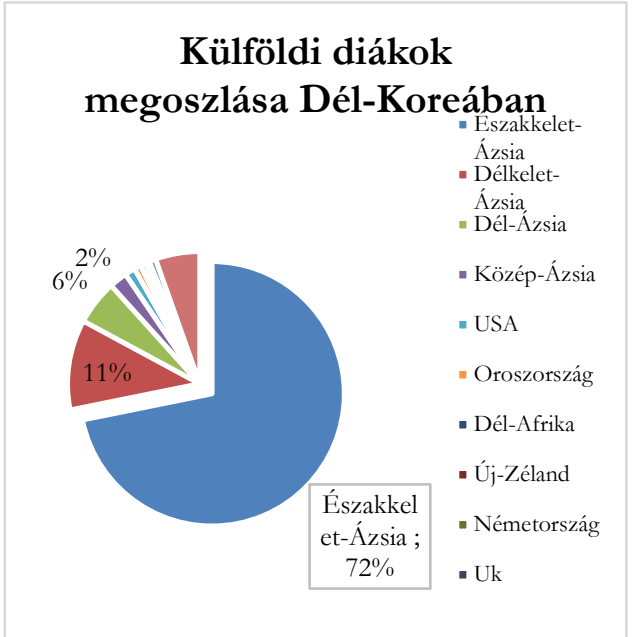

\section{Külföldi diákok aránya az összes diákhoz mérve Dél-Koreában}

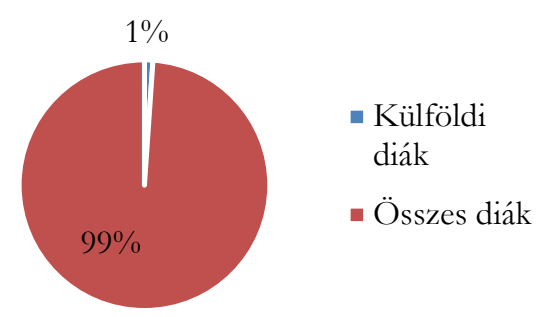

10. számú ábra: A külföldi diákok megoszlása Dél-Koreában. ${ }^{60}$

A 2. számú táblázatból látszik, hogy Dél-Korea jóval több médiatartalmat exportál, mint amennyit importál. Az évek során folyamatos növekedés volt tapasztalható, mind az export, mind az import oldalon (15. ábra). Ez is mutatja az ország elköteleződését a hallyu mellett, illetve annak folyamatos támogatását. A koreai kultúra további népszerűsítése érdekében kiválasztotta az ország top 10 szimbólumát, amelyeket fokozott mértékben reklámoznak PR tevékenységeik során ${ }^{61}$.

\begin{tabular}{|l|c|c|c|c|}
\hline & $\mathbf{2 0 1 5}$ & $\mathbf{2 0 1 6}$ & $\mathbf{2 0 1 7}$ & $\mathbf{2 0 1 8}$ \\
\hline Helyi termelés & $4,791.29$ & $4,801.12$ & $4,897.14$ & $4,995.08$ \\
\hline Export & $2,399.42$ & $2,412.41$ & $2,460.66$ & $2,509.87$ \\
\hline Import & 708.75 & 715.41 & 729.71 & 766.19 \\
\hline $\begin{array}{l}\text { Import } \\
\text { Amerikából }\end{array}$ & 421.55 & 465.67 & 474.98 & 479.72 \\
\hline
\end{tabular}

2. számú táblázat: Szórakoztató- és médiaipar export-import millió USA dollárban. ${ }^{62}$

\footnotetext{
${ }^{60}$ KOSIS (2019c)

${ }^{61}$ KANG, 2015.

62 export.gov (2018)
} 


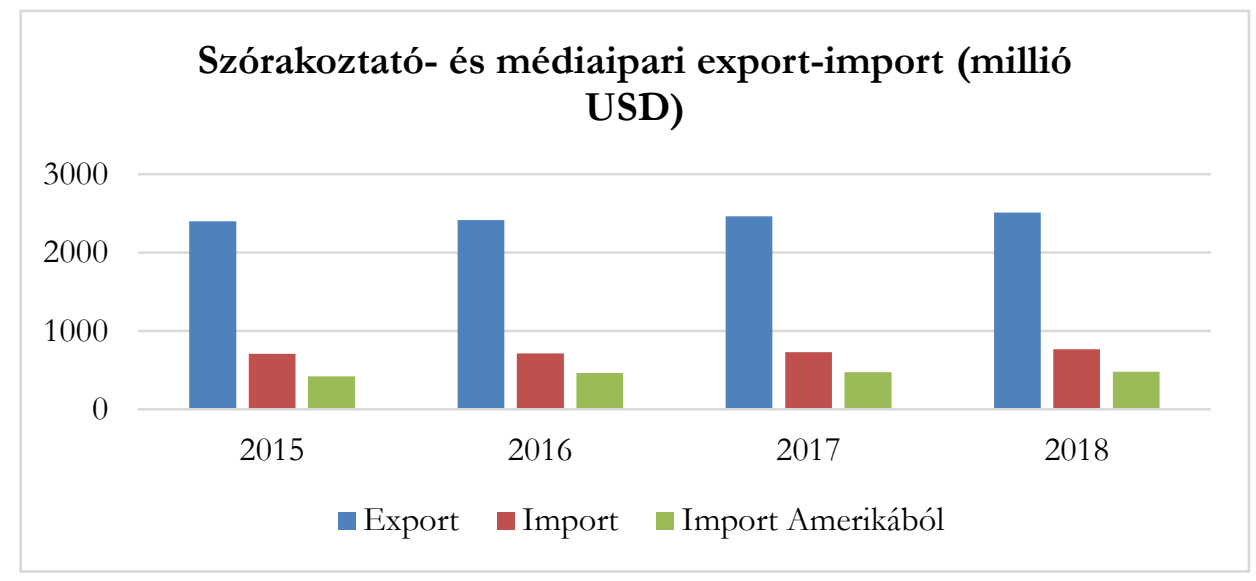

11. számú ábra: Szórakoztató- és médiaipari export-import (millió USD) ${ }^{63}$

Összességében láthatjuk, hogy a hallyu különféle elemei (film, zene, tv) nagy hatással vannak a kultúra terjesztésére. Kis ország létére Dél-Korea viszonylag sok filmet gyárt és zenét exportál, mely az egy főre eső adatokon is meglátszik. Ezek segítségével tudja a kultúráját is terjeszteni, s vonzóvá tenni az országot.

\subsection{Politikai értékek, ideológiák}

A politikai értékek és ideológiák lényege, hogy nemzetközileg és országon belül is elfogadott, konzisztens és minél jobban elterjedt legyen. Ahhoz, hogy minél több országba eljusson az ideológia, arra van szükség, hogy minél több nemzetközi szervezetnek a tagja legyen az adott ország.

\subsubsection{Kína}

A kínai politikát és értékeket nagymértékben befolyásolta a konfucianizmus, de emellett jelenleg a kommunizmus a meghatározó eszme. Jordán Gyula inkább a kapitalizmushoz hasonlította a politikai berendezkedést, amely sok kínai jellemzővel van átalakítva. Bárhogy is nevezzük, létezik egyfajta ideológiai szakadék Kína és a többi kapitalista értékeket

63 export.gov (2018) 
követő ország között. Ezt több diplomáciai lépéssel próbálják áthidalni, például a média segítségével, amellyel az emberek véleményét igyekeznek formálni Kínáról. ${ }^{64}$

A médián kívül van egy fontos faktor, ami befolyásolja a külvilág Kínáról alkotott képét. Ez az ország gyors gazdasági növekedése, melyben sok ország a követendő példát látja. ${ }^{65}$ Kína ezenkívül egyre több nemzetközi szervezetben vesz részt aktív tagként, ilyen például a Dél-Ázsiai Nemzetek Szövetsége (ASEAN), a G-20, a WTO és az UNESCO. Összesen 65 szervezetnek a tagja és még 10-ben megfigyelőként van jelen. ${ }^{66}$ Ami viszont az ország egyik legnagyobb hátránya, az a demokrácia hiánya és a gazdasági kiegyensúlyozatlanság. ${ }^{67}$ Több kutatás is bizonyította, hogy leginkább a kínai autokrata vezetéssel és az emberi jogok védelmének alacsony mértékével nem értenek egyet az emberek. ${ }^{68}$

A kínai politikában van egy erőteljes negatív propaganda azokkal az országokkal szemben, akik nem vallanak hasonló értékeket, mint ők, ilyen például Amerika vagy Japán. Ez az erôteljes antiamerikanizmus és negatív propaganda viszont elsősorban az ország belföldi politikájának része, annak a legitimitásának növelése a célja. Ehhez egyrészt egy erőteljes kínai öntudatot építenek, illetve más országokat vagy egyéneket, mint ellenség tüntetnek fel. ${ }^{69}$

\subsubsection{Korea}

A koreai politika egyik legnagyobb sikere, ami mind külföldi mind belföldi körökben szimpátiát vált ki az emberekből, az a sikeres modernizáció és demokratizáció. Sok fejlődő ország számára ez a modell nagyon imponáló és emiatt még koreai tanácsadókat is felkérnek arra, hogy segítsenek a saját országuk fejlesztésében. Ami kissé megnehezíti Dél-Korea helyzetét, az az Észak-Koreával való viszonya. Azonban Dél-Korea próbál minél jobb megoldást találni a helyzetre és a nemzetközileg is elfogadok normák és értékek szerint eljárni. ${ }^{70}$

\footnotetext{
${ }^{64} \mathrm{ZHAO}, 2015$.

65 JORDÁN, 2010.

${ }^{66}$ THE WORLD FACTBOOK, 2019A.

${ }^{67}$ CHO-JEONG, 2008.

${ }^{68}$ HOLYK, 2011.

${ }^{69}$ CaLlahan, 2015.

${ }^{70}$ LEE, 2009.
} 
Az állam emellett a koreai hullámot támogatja, méghozzá úgy, hogy törvényeket és szervezeteket hoz létre a kulturális szektorban. Ezzel nem csak a külföldi megjelenését a ballyunak, de a belföldi megitélését akarta növelni. Az állam az éves büdzsé több mint 1\%-át költötte erre a szektorra, már a 2000-es évek elején is. ${ }^{71}$

Dél-Korea emellett több nemzetközi szervezetnek is a tagja, a fontosabbakkal együtt (WTO, G20, UNESCO, ASEAN) összesen 69 szervezetben tag és még további 7-ben megfigyelő státuszban van jelen ${ }^{72}$. A politikai rendszerüket közvélemény kutatások alapján hasonlóan elfogadhatónak tartják, mint a japán vagy az amerikai rendszert, azonban a délkelet-ázsiai régiókban a kínai rendszernek nagyobb sikere van. ${ }^{73}$

Összességében tehát a Dél-Korea politika közelebb áll a nemzetközi trendekhez (például a demokrácia és az emberi jogok szintje), emiatt könnyebben elfogadják őt, mint központi hatalmat.

\subsection{Külpolitika}

A külpolitika akkor számít a puha hatalom forrásának, ha az törvényes és erkölcsileg is elfogadott. A növelésében segít például a más országoknak adott segélyek mértékének növelése is. Bevándorlók mennyisége egy jó mérőszám lehet a külpolitikai sikerességnek.

\subsubsection{Kína}

Nyilvános diplomáciai kampányt 2003 óta folytat az ország, amely délkoreai és japán színészeket céloz meg, hogy együttmúködés által pozitív benyomást tegyen a környező országokra. Kína az elmúlt években egyre több figyelmet fordított a körülötte levő országokkal való jó kapcsolat kialakítására és a „jó szomszéd politika” segítségével egyre jobban véleményvezérré válik a régióban. A diplomáciáját a kapcsolati diplomáciai modell írja le, amelynek lényege, hogy a nemzetközi szervezetek, NGO-k és a közmédia is nagy szerepet játszanak a diplomáciai kapcsolatok építésében. ${ }^{74}$

\footnotetext{
${ }^{71}$ KANG, 2015.

72 THE WORLD FACTBOOK, 2019B.

${ }^{73}$ HOLYK, 2011.

${ }^{74}$ ZHAO, 2015.
} 
A kínai külpolitika egyik legmeghatározóbb elemei az elmúlt évek során a 2003-as békés növekedés elmélete és a 2004-es Pekingi Konszenzus volt. A Pekingi Konszenzust egy Joshua Cooper Ramo nevű szenior tanácsadó és egyetemi professzor fejlesztette ki, mint egyfajta alternatívát a Washingtoni Konszenzusra, mely 3 tételből áll: [1] Kína fejlődése az innováción alapul, [2] a kínai fejlődésben a fenntarthatóság és az igazságosság fontos prioritás és [3] hogy Kína az önrendelkezésre törekszik a külpolitikában. Ezzel elsősorban a kínai fejlődési modell népszerűsítése, illetve az amerikai értékek kritizálása volt a cél. Ramo állításait azóta több kritika is érte, például, hogy az innovációt a külföldi múködőtőkének köszönheti és a kormány erre csak az utóbbi években kezdett figyelmet fordítani ${ }^{75}$. Azonban Kína bizonyos fejlődési tapasztalatai, amelyek le vannak írva a Pekingi Konszenzusban is, fontos inputokat jelentenek más ázsiai, afrikai és latin-amerikai fejlődő országok számára. A békés növekedés politika viszont sokkal inkább a tényleges külpolitikára fókuszál, és célja, hogy Kína segítségével Ázsiában egy USA centrikus külgazdaság helyett egy szomszédság központú diplomácia alakuljon ki. ${ }^{76}$

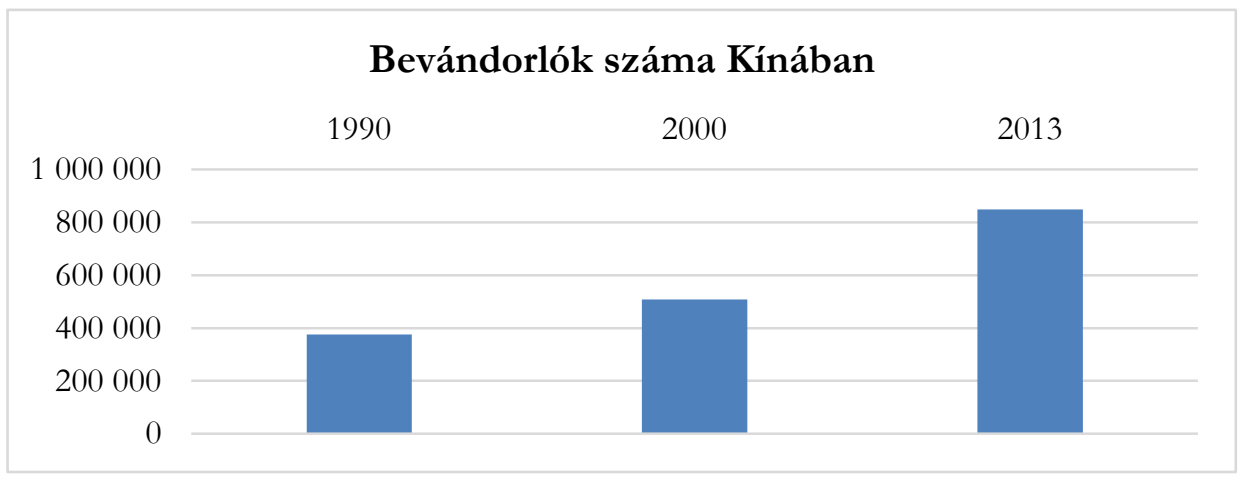

12. számú ábra: Bevándorlók száma Kínában. ${ }^{77}$

Kína ezen kívül sok országba befektet, illetve segélyeket is nyújt. Az egyik legnagyobb reputációja Afrikában van. Ennek oka, hogy Kína már évtizedek óta nyújt segítséget afrikai országok számára nem csak segélyek, de egyéb hosszútávú befektetések útján is ${ }^{78}$. Ezt több ország is kritizálja,

\footnotetext{
75 JORDÁN, 2010.

${ }^{76}$ CHO-JEONG, 2008.

77 UNICEF (n.a)

${ }^{78}$ HUNTER, 2009.
} 
hiszen ezzel Kína diktátorokat is támogat, s ez a nézet nem tesz jót a nemzetközi megítélésének sem. ${ }^{79}$

A külpolitikai sikeresség egyik mérőszáma a bevándorlók aránya. Az UNICEF által kiadott közlemény szerint a nettó migráció, vagyis a bevándorlók és a kivándorlók különbsége negatív, vagyis több ember költözik külföldre, mint amennyien bevándorolnak. ${ }^{80} \mathrm{Az}$ bevándorlás az évek során növekvő tendenciát mutat, azonban arányuk az egész ország népességéhez mérten elenyésző.

\subsubsection{Korea}

A ballyu jelensége a diplomácia területére is jótékony hatással van, például a történelmi ellentét ellenére a koreai televíziós drámák és popkultúra közelebb hozta a két nemzetet. ${ }^{81}$

A koreai külpolitika célja a nemzetközi piac szélesítése az ország exportja számára, beleértve a külföldi működőtőke beáramlását és a turisták számának növelését. ${ }^{82}$ Ezenkívül Dél-Korea meghatározott kultúrán alapuló diplomáciai célokat is, amelyek a következők: bilaterális kapcsolatok erősítése, kétoldalú kulturális csereprogramok, konferenciák tartása, egy Ázsiai Kulturális Együttmûködési szervezet megalapítása és a hallyu további támogatása. ${ }^{83}$

Dél-Korea csak az elmúlt időszakban kezdte alkalmazni a központi hatalmi státuszához illő külpolitikai stratégiát. Ennek megnyilvánulásai például a „Globális Korea” szlogen, az egyre több nemzetközi esemény rendezése, a zöld fejlődés felé történő orientáció és a regionális ügyekben való egyre aktívabb részvétel. Ezen felül Dél-Korea, aki egykor még maga szorult segélyekre, mára egyre nagyobb részben küld adományokat és missziókat egy-egy elmaradottabb területre. ${ }^{84}$

A nettó bevándorlók értéke 2006 óta pozitív, vagyis több ember érkezik az országba, mint amennyi elhagyja azt. (13. ábra) A bevándorlók aránya az összes népességhez mérten pedig jobb, mint Kína esetében.

\footnotetext{
${ }^{79}$ GiLL-HuANG, 2006.

${ }^{80}$ UNICEF, N.A.

81 THE KOREAN WAVE, 2011.

82 LEE, 2009.

${ }^{83}$ KANG, 2015.

${ }^{84}$ LEE, 2012.
} 


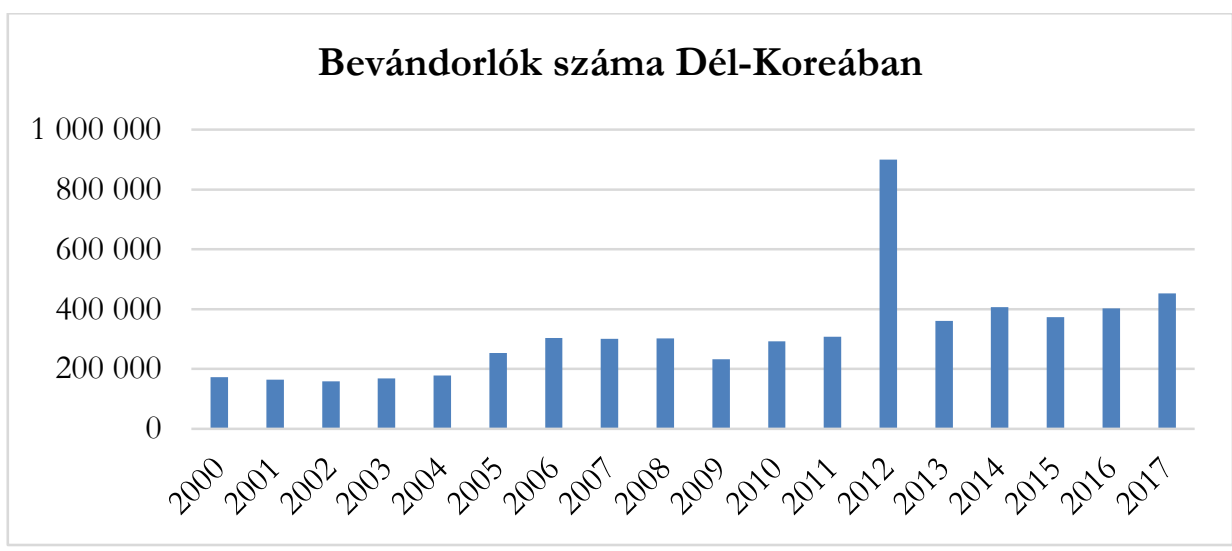

13. számú ábra: Bevándorlók száma Dél-Koreában. ${ }^{85}$

\section{KONKLÚZIÓ}

A kutatásom célja az volt, hogy megvizsgáljam a dél-koreai puha hatalmi forrásokat összehasonlítva a Kína számára rendelkezésre álló forrásokkal, illetve, hogy bemutassam a hallyu hatását a dél-koreai puha hatalmi forrásokra nézve. Ehhez korábbi tanulmányokat és Nye által javasolt mutatószámokat vizsgáltam az egyes erőforrásoknál.

Az elemzésből az erôteljesen kitűnik, hogy Dél-Koreánál mindegyik puha hatalmi forrás kategóriánál (kultúra, ideológiák, külpolitika) bizonyos mértékben megjelenik a hallyu hatása. A legerőteljesebben a kultúránál tűnik fel, hiszen a koreai hullám alapvető részei, vagyis a film, zene és televíziós műsorszórás, a kultúra kifejezésének forrásai. A politikai értékeknél inkább egy támogatott területként jelenik meg, míg a külpolitikánál egy csatornát biztosít a többi ország felé. Tehát azt egyértelműen meg lehet állapítani, hogy a hallyu egy fontos erőforrás a dél-koreai állam számára, ha a puha hatalomról van szó.

A kultúra, mint puha erőforrás első látásra Kínánál lenne a nagyobb, annak történelmi nagysága, a régióban betöltött szerepe, illetve az egyik fö eszméje, a konfucianizmus elterjedésének következtében. Azonban ennek népszerűsítését például filmek segítségével, csak az elmúlt időszakban kezdte el. Ezzel szemben Dél-Koreában a nyelv könnyen tanulhatósága és a

\footnotetext{
${ }^{85}$ STATISTICS KOREA 2017.
} 
ballyu is hozzájárul a kultúra könnyebb elterjesztéséhez. Ezt a különféle mutatók, például a zeneipari export vagy a külföldi diákok aránya is mutatja.

A politikai nézetek és ideológiák terén is hasonló a helyzet: a koreai berendezkedés közelebb áll a főáramban lévő ideológiákhoz, mint a kínai. Azonban mind a két ország egy intenzív fejlődési időszakon van túl, amelyre példaként tekintenek a különféle országokban is, sôt vannak, akik inkább a kínai típusú politikával szimpatizálnak (például Délkelet-Ázsiában). A Nye által is meghatározott mutató, vagyis, hogy hány nemzetközi szervezetben vannak jelen, nagyjából ugyanannyi volt a két országnál, a különbség az összetételben volt észlelhető. Míg Kína nagyságánál fogva több G-20-hoz hasonló szervezet tagja, addig Dél-Korea több Európához kapcsolódó szervezetben van jelen.

A külpolitikát tekintve Kína az elmúlt időszakban nagyon sokat fejlődött és próbál egy „jó szomszédi politikát” fenntartani, míg Korea egy, a központi hatalmi státuszához illő stratégiát követ, melynek része a hallyu is, hiszen ennek segítségével tudtak egy jobb kapcsolatot kialakítani például Japánnal is. Ezen kívül mindkét ország nyújt segélyeket más országoknak, Kína viszont különös figyelmet szentel Afrikának. A bevándorlók számán az látszik, hogy bár abszolút értékben Kínában több a bevándorló, azonban Korea nagyságához képest arányaiban több külföldi telepedik le náluk.

A Nye (2004) által meghatározott három, a hiteles állam képének kialakításához szükséges stratégiai irányokban, vagyis hogy az ország kultúrája közel áll a nemzetközi irányzathoz, sok médiacsatornán keresztül próbálja terjeszteni elveit, illetve hogy az évek során kiérdemelte-e a bizalmat, Dél-Korea jobban teljesít. A kultúrájuk történelmi okok miatt jobban az főáramhoz tendál, a ballyun keresztül sok média megjelenéssel rendelkezik, illetve az elmúlt évek diplomáciai lépései is segítettek a nemzetközi elismerés elnyerésében. Kína, bár egyre több médiában van jelen, de kultúrája távol helyezkedik el a globális irányzathoz képest és még sok kétes érzés van az embereknek, fóleg az ország politikája és jogrendszere miatt. Azonban, ha Kína a következő időszakban is folytatja a puha hatalom növelésére irányuló politikáját, akkor még meghatározóbb szerepet tölthet be a világgazdaságban.

Kutatásom korlátja egyrészt a hatalmi források nehezen mérhetősége, másrészt az országok nagysága miatti abszolút számok közötti különbség. Így, ahol lehetett, arányszámokat használtam, például az egy fơre levetített könyvexport mértékét. További korlátot jelentett az egyes adatok vagy megtisztított adatok hiánya, illetve a nyelvi korlátok bizonyos esetekben. 
Éppen ezért a jövőbeli kutatási lehetőségek között szerepelhet egy nagyobb adattgyüjtés utáni további elemzés is. A hallyu magában is egy nagyon újszerű és viszonylag fiatal téma, amire érdemes lehet a következő években még jobban odafigyelni és vizsgálni a gazdasági növekedésre vagy a társadalomra való további hatásait.

\section{FELHASZNÁLT IRODALOM}

BOK-RAE, K. (2015): Past, Present and Future of Hallyu (Korean Wave). American International Journal of Contemporary Research. Vol.5. No.5. DOI azonosító: $10.30845 /$ aijcr

BrÁCZ, G. és OrSZÁGH, L. (szerk.) (2016): HATALOM in A magyar nyelv értelmező szótára. Elérhető: http://mek.oszk.hu/adatbazis/magyarnyelv-ertelmezo-szotara/kereses.php?kereses=hatalom (Letöltve: 2019. április 11.)

Callahan, W. A. (2015): Identity and Security in China: The Negative Soft Power of the China Dream. Political Studies Association. Vol 35 (3-4). 216-229. DOI azonosító: DOI: 10.1111/1467-9256.12088

Cho, Y. N. és Jeong, J. H. (2008): China's Soft Power: Discussions, Resources, and Prospects. Asian Survey, Vol. 48. No. 3 (May/June 2008). pp. 453-472

Csoma, M. (2013): Korea. Egy nemzet, két ország - A közös gyökerektől. Napvilág Kiadó

EXPORT.GOV (2018): Korea - Entertainment and Media. Elérhető: https://www.export.gov/article?id=Korea-Entertainment-and-Media (Letöltve: 2019. április 16.)

GiLL, B., HuANG, Y. (2006): Sources and limits of Chinese 'soft power'. Survival. 48:2. 17-36. DOI azonosító: DOI:

$\underline{10.1080 / 00396330600765377}$

HASHimoto, K. (szerk.) (2018): Japanese Language and Soft Power in Asia. Springer Nature. Singapore. DOI azonosító: 10.1007/978-981-10-5086-2 HolyK, G. G. (2011): Paper Tiger? Chinese Soft Power in East Asia. Political Scinence Quarterly. Vol. 126. No. 2. 223-254. DOI azonosító: https://doi.org/10.1002/j.1538-165X.2011.tb00700.x HunTer, A. (2009): Soft Power: China ont he Global Stage. Chinese Journal of International Politics. Vol. 2. 373-398. DOI azonosító: https://doi.org/10.1093/cjip/pop001 
JORDÁN, Gy. (2010): A kínai soft power kérdéséhez. Nemzet és biztonság. 50-65.o. Elérhető:

http:/ / www.nemzetesbiztonsag.hu/regi szamok.php?rsz=2\&ev=2010\& $\underline{\text { szam }=5}$ (Letöltve: 2019. április 20.)

Joseph S. Nye (2006): Think Again: Soft Power. Foreign Policy. February 23, 2006.

KANG, H. (2015): Contemporary cultural diplomacy in South Korea: explicit and implicit approaches. International Journal of Cultural Policy. 21:4. 433-447. DOI azonosító: DOI: 10.1080/10286632.2015.1042473

KEAN, M. (2010): Keeping Up with the Neighbors: China's Soft Power Ambitions. Cinema Journal. Vol. 49. No. 3 (Spring 2010), 130-135.o. DOI azonosító: 10.1353 /ci.0.0218

KIM, K., BAE, S. (2017): Hallyu and the Traditional Cultural Genes of Korea. Kritika Kultura 29. 318-339.o. DOI azonosító: http://dx.doi.org/10.13185/KK2017.02915

KOFIC (2019): Distribution of films screened in cinemas in South Korea from 2008 to 2018, by origin. Statista. Elérhető:

https://www.statista.com/statistics/625516/south-korea-market-sharefilms-domestic-foreign/ (Letöltve: 2019. április 13.)

KOREA IN THE WORLD (2018): World Competitiveness Ranking in 2017. Elérhetô:

http://kosis.kr/vis eng/nso/worldInEng/selectWorldInEng.do (Letöltve: 2018. december 15.)

KOREAN FILM COUNCIL (2019): Yearly Statistics. Elérhető:

http://www.koreanfilm.or.kr/eng/news/boxOffice Yearly.jsp?mode $=\mathrm{B}$ OXOFFICE YEAR\&selectDt $=2019 \&$ category $=$ ALL\&country $=\mathrm{K}$ (Letöltve: 2019. április 10.)

KOSIS (2019a): Projected Population by Age Group (Korea). Elérhető: http://kosis.kr/statHtml/statHtml.do?orgId=101\&tblId=DT 1BPA003 \&vw $\mathrm{cd}=$ MT ETITLE\&list $\mathrm{id}=\mathrm{A} 43 \& \mathrm{scrId}=\&$ seqNo $=$ \&language $=$ en \&obj var id=\&itm id=\&conn path=A6\&path=\%252Feng $\% 252$ Fsearc h\%252FsearchList.do (Letöltve: 2019. április 13.)

KOSIS (2019b): Statistical Database. Elérhetô:

http://kosis.kr/eng/search/searchList.do (Letöltve: 2019. március 20.) KOSIS (2019c): Foreign Students. Elérhető:

http://kosis.kr/statHtml/statHtml.do?orgId=110\&tblId=TX 11025 A $\underline{011 \& v w} \mathrm{~cd}=\mathrm{MT}$ ETITLE\&list $\mathrm{id}=\mathrm{A} \quad 7 \& \mathrm{scrId}=\&$ seqNo $=\&$ language $=$ 
en\&obj var id=\&itm id=\&conn path=A6\&path=\%252Feng $\% 252 \mathrm{Fse}$ arch\%252FsearchList.do (Letöltve: 2019. április 13.)

KSH (2018): A háztartások fogyasztása, 2017 (előzetes adatok). Statisztikai

Tükör március. Központi Statisztikai Hivatal. Budapest

LEE, G. (2009) A theory of soft power and Korea's soft power strategy.

Korean Journal of Defense Analysis. 21:2. 205-218.o.

LEE, S. J. (2012): South Korea as New Middle Power Seeking Complex Diplomacy. EAI Asia Security Initiative Working Paper. 25. Republic of Korea

LI, L. és Hong, X. (2012). The Application and Revelation of Joseph Nye's Soft Power Theory. Studies in Sociology of Science, 3 (2), 48-52.o. DOI azonosító: http://dx.doi.org/10.3968/j.sss.1923018420120302.9Z0210

LIM, S. és GIOUVRIS, E. (2017): Turist arrivals in Korea: Hallyu as a pull factor. Current Issues in Tourism. DOI azonosító: DOI: $\underline{10.1080 / 13683500.2017 .1372391}$

LiN, L. és HongtaO, L. (2017): Joseph Nye's Soft Power Theory and Its Revelation Towards Ideological and Political Education. Humanities and Social Sciences. Vol. 5, No. 2, 69-74.o. DOI azonosító: doi: 10.11648/i.hss.20170502.13

MALOTA E. (2013) Kultúrafogalmak és modellek. In: Malota E.-Mitev A., Kultúrák találkozása. Nemzetközi kommunikáció, kultúrsokk, sztereotípiák. Alinea Kiadó, Budapest, 1. fejezet, 11-50.o

Mingjiang, L. (2008): China Debates Soft Power. Chinese Journal of International Politics. Vol. 2. 287-308. doi:10.1093/cjip/pon011

MINISTRY OF EDUCATION (2019): Statistical report on international students in China for 2018. Elérhető:

http://en.moe.gov.cn/news/press releases/201904/t20190418 378586. html (Letöltve: 2019. április 21.)

MiNistRy OF EDUCATION (China) (2016): Number of foreign students studying in China in 2016, by country of origin. Statista. Elérhető: https://www.statista.com/statistics/430717/china-foreign-students-bycountry-of-origin/ (Letöltve: 2019. április 13.)

MiroudOT S. (2019): HALLYUWOOD Korea's Comparative Advantage in the Global Motion Picture Industry. Kritika Kultura 32 (2019): 5478.o. DOI azonosító: http://dx.doi.org/10.13185/2978

N.A. (2011): The Korean Wave: A New Pop Culture Phenomenon. Korean Culture and Information Service, Korea 
National Bureau of Statistics of China (2018): China Statistical Yearbook 2018. Elérhető:

http://www.stats.gov.cn/tjsj/ndsj/2018/indexeh.htm (Letöltve: 2019. április 13.)

National Bureau of Statistics of China (2019): Annual Data. Elérhető: http://www.stats.gov.cn/english/Statisticaldata/AnnualData/ (Letöltve: 2019. április 13.)

Nye, Joseph. S. (2011): The Future of Power. Public Affairs. New York

NyE, JosepH. S. (2017): Soft Power: the origins and political progress of a concept. Palgrave Communications. DOI azonosító: DOI: $10.1057 / \mathrm{palcomms} .2017 .8$

NYE, J.S. (2004): Power in a Global Information Age. Routledge. London STATISTICS Korea (2017): International M igration Statistics in 2017. Elérhetô:

http://kostat.go.kr/portal/eng/pressReleases/8/5/index.board (Letöltve: 2019. április 18.)

STATISTICS KOREA (2018): Value of music industry exports from South Korea from 2005 to 2016 (in million U.S. dollars). Statista. Elérhető: https://www.statista.com/statistics/625158/south-korea-export-musicindustry/ (Letöltve: 2019. április 11.)

STATISTICS KOREA (2019): Transaction value of online book sales in South Korea from 2011 to the third quarter of 2018 (in billion South Korean won). Statista. Elérhető:

https://www.statista.com/statistics/631088/south-korea-online-booksales/ (Letöltve: 2019. április 18.

THE WORLD FACTBOOK (2019a): EAST ASIA/SOUTHEAST ASIA :: CHINA Elérhető:

https://www.cia.gov/library/publications/resources/the-worldfactbook/geos/ch.html (Letöltve: 2019. április 13.)

THE WORLD FACTBOOK (2019b): EAST ASIA/SOUTHEAST ASIA :: KOREA, SOUTH. Elérhető:

https://www.cia.gov/library/publications/resources/the-worldfactbook/geos/ks.html (Letöltve: 2019. április 13.)

TRADE MAP (2019): List of products exported by Korea, Republic of. Elérhetô:

https://www.trademap.org/Product SelCountry TS.aspx?nvpm $=1 \% 7 \mathrm{c}$ $410 \% 7 \mathrm{c} \% 7 \mathrm{c} \% 7 \mathrm{c} \% 7 \mathrm{c} 49 \% 7 \mathrm{c} \% 7 \mathrm{c} \% 7 \mathrm{c} 4 \% 7 \mathrm{c} 1 \% 7 \mathrm{c} 1 \% 7 \mathrm{c} 2 \% 7 \mathrm{c} 2 \% 7 \mathrm{c} 1 \% 7 \mathrm{c} 1$ \%7c1\%7c1 (Letöltve: 2019. április 18.) 
UNICEF (n.a): Migration Profiles: Part I. Global legal instruments related to international migration. Elérhetô:

https://esa.un.org/miggmgprofiles/indicators/files/China.pdf (Letöltve: 2019. április 19.)

Visser, D. (2002, March 10). What Hip Asians want: A little bit of Seoul: from films to fashion, Korean pop culture becomes "Kim Chic" across continent. Washington Post (from the Associated Press). Elérhető: http://seattlepi.nwsource.com/national/56897 pac04.shtml (Letöltve: 2018. december 14.)

XINHUA News AgENCY (2018): Number of feature films produced in China from 2007 to 2017. Statista. Elérhető: https://www.statista.com/statistics/260392/number-of-feature-filmsproduced-in-china/ (Letöltve: 2019. április 10.)

ZHANG, GUOZUO (2017): Research Outline for China Cultural Soft Power. Social Sciences Academic Press. China. DOI azonosító: 10.1007/978$\underline{981-10-3398-8}$

ZHAO, K. (2015): Pubplic Diplomacy, Rising Power, and China's Strategy in East Asia in Melissen, J., Sohn, Y. (eds) Understanding Public Diplomacy in East Asia. Palgrave Macmillan. New York. DOI azonosító: $\underline{10.1057 / 9781137532299}$ 